
$\checkmark$ Research Square
Preprints are preliminary reports that have not undergone peer review.
They should not be considered conclusive, used to inform clinical practice,
or referenced by the media as validated information.

\title{
The Trade-Off Between Economic Performance and Environmental Quality: Does Financial Inclusion Asymmetrically Matter for Emerging Asian Economies?
}

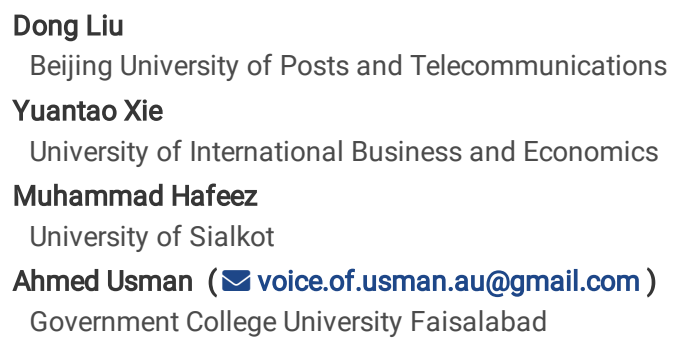

Dong Liu

Beijing University of Posts and Telecommunications

Yuantao Xie

University of International Business and Economics

Muhammad Hafeez

University of Sialkot

Ahmed Usman ( $\nabla$ voice.of.usman.au@gmail.com )

Government College University Faisalabad

\section{Research Article}

Keywords: Financial inclusion, Economic performance, $\mathrm{CO} 2$ emissions,

Posted Date: September 13th, 2021

DOI: https://doi.org/10.21203/rs.3.rs-834441/v1

License: (c) (1) This work is licensed under a Creative Commons Attribution 4.0 International License. Read Full License

Version of Record: A version of this preprint was published at Environmental Science and Pollution Research on January 7th, 2022. See the published version at https://doi.org/10.1007/s11356-021-17755-1. 


\section{Abstract}

This study examines the role of financial inclusion on the environment-economic performance in the top five Asian emerging economies. The data used for empirical investigation covers the time period from 1995 to 2019. Financial inclusion is measured through bank branches, bank credit, and insurance premiums. To check long-run associations, the panel-ARDL approach has been employed for empirical analysis. The empirical evidence confirms the significant associations between financial inclusion-GDP nexus and financial inclusion-CO2 nexus. The findings show that bank branches and bank credit have a significantly positive impact on economic growth and $\mathrm{CO} 2$ emissions in the long-run. However, insurance premium has no impact on economic growth but it exerts a significant negative impact on carbon emissions in the long-run. Furthermore, energy consumption is highly sensitive to economic growth and carbon emissions. The study delivers imperative points for pollution eradication and attaining sustained economic growth. There is a need for governmentlevel efforts to align the targets of financial inclusion with economic growth and environmental policies.

\section{Introduction}

It was the early 1990s when the term financial exclusion came to the fore and pointed out the inadequate amount of bank branches and the limited accessibility to these branches as a big hurdle in a more liberal, dynamic, and vibrant financial sector (European Commission, 2008). Previously, the term financial exclusion was used to define obstacles to access the primary financial services and goods from the point of view of both users of these services (demand side) and producers of these services (supply side) (Rahim et al., 2009). To promote financial inclusion demand-side works side by side the supply side. Poverty is the main factor that hinders financial inclusion because if a majority of people are living below the poverty line they don't have enough savings to deposit in the bank accounts. Likewise, if the pace of the economy is slow then the level of investment in the economy is also sluggish resulting in low demand for loans and other financial services. The tendency to save more can shift the poor people from low-income brackets to higher ones thus increasing their role in banks and financial institutions which can cause the financial services to push upwards (Reserve Bank of India, 2013). Reserve bank of India (RBI) defines financial inclusion as, "the process of ensuring access to appropriate financial products and services needed by vulnerable groups such as weaker sections and low-income groups at an affordable cost fairly and transparently by mainstream institutional players."

Over the past few decades, financial inclusion has grabbed the attention of academics, policymakers, and other stakeholders in the financial industry. The implied reason behind this interest in financial inclusion is its role in improving economic development and eradicating poverty. Financial inclusion simply means the easy provision of mainstream financial facilities such as bank accounts, deposits, loans, insurance facilities, etc., not only for individuals but for firms, businesses, and all stakeholders. In other words, we can say that a high level of financial inclusion allows all the stakeholders in the economy to take full advantage of the basic financial services which can help them to grow and make them financially stable (Kim et al., 2018). On the other side, in the economies where the financial sector is not developed enough, the people suffer to get enough support from the financial sector in the case of financial problems. According to a report published, in 2020, by the global partnership on financial inclusion (GPFI), despite the impressive growth in the availability of financial services since 2011 , about $30 \%$ of the adults in the world are still deprived of financial services.

The role of financial inclusion in improving the growth of the economy is well known (Makina et al. 2019 and Dahiya et al. 2020 and Singh \& Stakic, 2021). Financial inclusion brings the people into the mainstream economy by connecting them to the banks and other financial services which helps the economy to grow at a fast pace (Sharma, 2016). A financial institution aids in the smooth working of a comprehensive financial arrangement, which assists in channelling capital from investors to debtors and grease the controls of the economy transparently. The empirical proof displays that there is a positive association between financial inclusion and economic growth regardless of country (see Swamy, 2010; Van et al., 2021). It supports the attainment of financial facilities in all segments of society at a reasonable cost (Ahmad et al. 2021).

Theoretically, financial inclusion may affect the environmental quality in either way i.e. positive or negative (Le et al. 2020; Raheem et al., 2020; and Qin et al., 2021). With an improvement in the financial sector inclusivity increases which permits the firms and businesses to get easy loans from the banks and other financial institutions and enables them to develop and invest more in clean ad green technology. In this respect, financial systems with inclusive properties can fetch satisfactory influences on the environmental quality as an instrument to surge the convenience, affordability, and acceptance of healthier environmental customs that diminish its role in climate change (IPA, 2017). Baulch et al. (2018) discovered that in Vietnam financial restraints such as the non-availability of credits and loans from banks, financial institutions and government curtailed the flow of investments in renewable energy sources. Based on such examples one can easily say that a developed and sound financial system with more access to capital, loans, and other financial products can remove the hurdles in the way of investments in clean and green technology thus leading to reduce the consumption of non-renewable energy sources and consequently curb the $\mathrm{CO} 2$ emissions. The negative effects of financial inclusion come from the process of financial development which makes the process of investments in large projects much easier due to easy access to loans and credits and thus increases energy consumption and CO2 emissions (Le et al., 2020). As a result of a high level of financial inclusion, individuals can also take loans from banks and other financial institutions and purchase more energyintensive products such as cars, freezers, microwaves, washing machines, and air-conditioners, which can seriously increase the consumption of energy obtained from non-renewable sources, hence, causing the $\mathrm{CO} 2$ and other greenhouse gas emissions to rise. Moreover, the higher the level of inclusiveness in the financial system the higher will be the level of economic development which is largely dependent on energy consumption coming from fossil fuels, eventually give rise to $\mathrm{CO} 2$ emissions in the atmosphere (Emara et al., 2021).

From the above discussions, we can deduce that financial inclusion is important not only for economic development but have long-lasting effects on the environment as well. Over the past few decades, emerging Asian economies are fortifying their place among the world's nations both politically and economically, hence capturing the impact of financial inclusion on environmental quality and economic growth in emerging Asian economies is an interesting topic. Consistent with this view, we have included the financial inclusion variable in the economic growth and carbon emission functions of emerging Asian economies. This is the first-ever study, in the context of emerging economies. To that end, we have applied linear panel ARDL analysis by gathering data over 
the period 1995-2019. The structure of the study is as follows. Section two describes the data and methods followed by the results and discussions in section three. In section four, we conclude the study.

\section{Methods And Data}

To capture the impact of financial inclusion on economic growth and $\mathrm{CO} 2$ emissions in Asian emerging economies, we have borrowed the following long-run model from Van et al. (2021) and Zaidi et al. (2021).

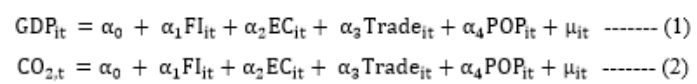

In the above models (1) and (2), GDP per capita (GDP) and carbon emissions $\left(\mathrm{CO}_{2}\right)$ are taken as the dependent variables and among the independent variables, financial inclusion (FI) is included as the main variable, while energy consumption (EC), Trade, and population are control variables in our analysis. The model discussed above is a long-run model and to get short-run estimates, as well, we describe this model in the form of error correction format. In doing so, we rely upon a method that gives estimates of long-run effects with short-run effects in a single step as follows:

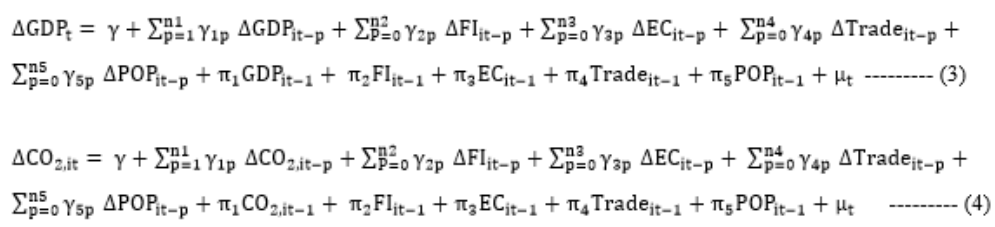

Pesaran et al. (2001) described equations (3) \& (4) as panel ARDL. It demonstrates both the short and long-run estimates. The estimates of the first differenced $(\Delta)$ variables provide the short-run results and the estimates - normalized on provide the long-run results. However, the long-run results are considered genuine only if they are co-integrated and the co-integration among the variables is confirmed through the negative and significant estimate attached to $\mathrm{ECM}_{\mathrm{t}-1}$. To get the estimate of $\mathrm{ECM}_{\mathrm{t}-1}$ first, we generate a series of residuals labelled as ECM by using equations (3 \& 4). We then replace the lagged value of this series $\left(\mathrm{ECM}_{\mathrm{t}-1}\right)$ in equations $(3 \& 4)$ in place of the lagged-level variables and estimate the new equation with the same number of lags as used originally. The size of the estimate attached to $\mathrm{ECM}_{\mathrm{t}-1}$ describes the speed of adjustment towards long-run equilibrium. This method has the advantage that it can estimate efficiently for the small number of observations. Moreover, this technique can take care of the integrating properties of the variables i.e. we should not worry about whether the variable is stationary at level or first difference because it can accommodate the mixture of variables with I(0) and I(1). Both tests have used their own tabulate new critical values for testing. The Hausman test is used to confirm the ARDL-PMG or ARDL-PM models are sufficient for this empirical analysis. In the end, we check causality in a non-linear framework by conducting the panel causality test of Hatemi-J (2012).

\section{Data}

For empirical investigation, data has been taken for the period ranging from 1995 to 2019 for the top five emerging economies of Asia including China, India, Japan, Indonesia, and Turkey. Table 1 provides a discussion on complete definitions of variables, their abbreviations, and descriptive analysis of data. Data on GDP per capita, carbon emissions, energy use, trade, and population growth is sought from the World Bank. However, data on bank branches, bank credit, and insurance premiums are sourced from IMF. GDP per capita is measured at constant 2010 US\$. Data on carbon emissions are measured in kilotons. Bank branches are taken as bank branches per 100,000 adults. Bank credit is measured as bank deposits in percentage. Data on life and non-life insurance premium volume to GDP (\%) is taken to measure insurance premium. Data series on energy use is measured as kg of oil equivalent per capita. Trade is measured in percentage of GDP. The annual percentage of population growth is used to measure the population growth variable.

\section{Table 1: Definitions and data sources}

\begin{tabular}{lllllll} 
Variables & Symbol & Definitions & Mean & Std. Dev. & Min & Max \\
\hline GDP per capita & GDP & GDP per capita (constant 2010 US\$) & 8.615 & 1.305 & 6.514 & 10.80 \\
\hline CO2 emissions & CO2 & CO2 emissions (kt) & 13.80 & 1.156 & 12.03 & 16.25 \\
\hline Bank branches & BB & Bank branches per 100,000 adults & 16.11 & 10.47 & 4.165 & 36.59 \\
\hline Bank credit & BC & Bank credit to bank deposits (\%) & 4.503 & 0.631 & 3.446 & 5.821 \\
\hline Insurance premium & Insurance & Life and non-life insurance premium volume to GDP (\%) & 3.005 & 2.409 & 0.690 & 8.468 \\
\hline Energy use & EC & Energy use (kg of oil equivalent per capita) & 7.121 & 0.711 & 5.953 & 8.315 \\
\hline Trade & Trade & Trade (\% of GDP) & 42.96 & 13.44 & 16.67 & 96.18 \\
\hline Population growth & POP & Population growth (annual \%) & 0.992 & 0.606 & -0.209 & 1.919
\end{tabular}




\section{Empirical Results And Discussion}

Panel-ARDL requires that none of the variables in the model is I(2) and the panel unit root tests tell us about the stationarity of our variables To that end, we have used panel unit root tests namely Levin, Lin and Chu (LLC), I'm, Pesaran and Shin (IPS) and ADF-Fisher. The results of the LLC show that most of the variables are stationary at first difference except BC, Insurance, and POP. However, when we apply IPS and ADF tests all the variables are stationary at first difference except the variable of POP. Table 2 findings confirm that we can apply the panel-ARDL technique. As the frequency of our data is annual we have imposed a maximum of three lags and optimal lag selection is based on Akaike Information Criterion (AIC).

Table 2: Panel unit root testing

\begin{tabular}{|c|c|c|c|c|c|c|c|c|c|}
\hline & LLC & & & IPS & & & $A D F$ & & \\
\hline & $\mathrm{I}(0)$ & $\mathrm{I}(1)$ & & $\mathrm{I}(0)$ & $\mathrm{I}(1)$ & & $\mathrm{I}(0)$ & $\mathrm{I}(1)$ & \\
\hline GDP & -0.634 & $-5.856 * \star \star$ & $\mathrm{I}(1)$ & -0.072 & $-3.760 * \star \star \star$ & $\mathrm{I}(1)$ & 0.432 & $-5.918^{\star \star *}$ & $\mathrm{I}(1)$ \\
\hline $\mathrm{CO} 2$ & -1.663 & $-6.749 * \star \star *$ & $\mathrm{I}(1)$ & -1.159 & $-4.233^{\star \star \star}$ & $\mathrm{I}(1)$ & 1.023 & $-7.125^{\star \star \star}$ & $\mathrm{I}(1)$ \\
\hline BB & -1.643 & $-4.004 * \star$ & $\mathrm{I}(1)$ & -0.423 & $-2.114^{\star}$ & $\mathrm{I}(1)$ & -1.035 & $-1.582^{\star}$ & $\mathrm{I}(1)$ \\
\hline BC & $-3.744^{\star}$ & & $\mathrm{I}(0)$ & -0.866 & $-2.831^{\star \star \star *}$ & $\mathrm{I}(1)$ & 0.787 & $-3.578^{\star}$ & $\mathrm{I}(1)$ \\
\hline Insurance & $-2.708^{*}$ & & $\mathrm{I}(0)$ & -1.119 & $-5.060 * \star \star$ & $\mathrm{I}(1)$ & 1.197 & -9.123 & $\mathrm{I}(1)$ \\
\hline EC & -1.359 & $-8.253^{\star \star \star}$ & $\mathrm{I}(1)$ & -0.657 & $-5.015^{\star \star \star}$ & $\mathrm{I}(1)$ & 0.374 & $-9.060^{\star \star \star}$ & $\mathrm{I}(1)$ \\
\hline Trade & -1.006 & $-5.766^{\star \star \star}$ & $\mathrm{I}(1)$ & -1.597 & $-4.910 * \star \star *$ & $\mathrm{I}(1)$ & -0.110 & $-8.752^{\star \star \star}$ & $\mathrm{I}(1)$ \\
\hline POP & $-2.571^{\star *}$ & & $\mathrm{I}(0)$ & $-2.490 *$ & & $\mathrm{I}(0)$ & $-2.012^{\star \star}$ & & $\mathrm{I}(0)$ \\
\hline
\end{tabular}

Note: ${ }^{* \star} \mathrm{p}<0.01 ; * \star \mathrm{p}<0.05 ;$ and ${ }^{*} \mathrm{p}<0.1$

After confirming the preliminary condition of Panel-ARDL we are now in a position to start the discussion on the estimates of our variables. Our dependent variables are GDP and $\mathrm{CO} 2$ emissions and we have used three different proxies of financial inclusion; bank branches, bank credit, and insurance. For both GDP and $\mathrm{CO} 2$ models we have included all the proxies of financial inclusion one by one. Table 3, shows the results of both in the short and long run. Moreover, cointegration tests and other diagnostics are also reported in table 3. First of all, we want to confirm whether our long-run results are cointegrated or not. Two tests of cointegration i.e. $\mathrm{ECM}_{\mathrm{t}-1}$ and Kao confirm that our long-run estimates of GDP and $\mathrm{CO} 2$ are cointegrated meaning they are genuine or valid. Hausman test results have supported the panel ARDL-PMG model. First, we discuss the long-run results of the GDP and CO2 models in detail, and then the short-run results in brief.

The long-run estimates of BB and BC, in the GDP model, are positively significant and in the case of Insurance, the estimate is insignificant. As the variables are taken in the log form we can explain them by saying that a $1 \%$ increase in the bank branches and bank credits facilities improve the GDP by $0.021 \%$ and $0.271 \%$. The estimate of bank credit is large as compared to the estimate of bank branches suggesting that instead of the number of branches, improved credit facilities are more helpful in increasing the GDP of the economy. As the number of branches and credit facilities in an economy increases the production activities also increase due to the easy availability of loans and other financial services for investment in large projects that can help the economy to grow at a great pace. Moreover, financial inclusion connects a large number of people to the financial system of the country that brings them into the mainstream economy which also helps in the development of the economy (Sharma, 2016).

Table 3: Panel-ARDL estimates of GDP and $\mathrm{CO} 2$ emissions 
(1) (2) (3)

(4) (5)

(6)

\begin{tabular}{|c|c|c|c|c|c|c|c|c|c|c|c|c|}
\hline Variable & Coefficient & t-Stat & Coefficient & t-Stat & Coefficient & t-Stat & Coefficient & t-Stat & Coefficient & t-Stat & Coefficient & t-Sta' \\
\hline \multicolumn{13}{|l|}{ Long-run } \\
\hline BB & $0.021^{\star \star \star}$ & 6.507 & & & & & $0.015^{\star \star \star}$ & 4.686 & & & & \\
\hline BC & & & $0.271^{* *}$ & 2.159 & & & & & 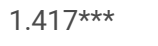 & 2.718 & & \\
\hline INSURANCE & & & & & 0.088 & 0.506 & & & & & -0.181 *** & $3.43:$ \\
\hline EC & $0.853^{\star * \star}$ & 5.726 & 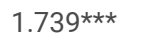 & 6.014 & 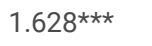 & 6.481 & $1.259 * \star \star$ & 8.864 & $1.992^{\star \star \star}$ & 4.118 & $1.635^{\star \star \star}$ & $23.6 !$ \\
\hline TRADE & $0.032^{\star \star \star}$ & 3.918 & $0.039 * * *$ & 2.026 & $0.012^{\star \star \star}$ & 3.577 & -0.001 & 0.539 & 0.006 & 1.251 & $-0.004^{\star \star *}$ & 3.67\{ \\
\hline POP & $0.458^{\star \star \star}$ & 5.766 & 0.624 & 0.810 & 0.384 & 1.563 & $-0.557 \star \star \star *$ & 6.158 & 0.678 & 1.070 & 0.002 & $0.02:$ \\
\hline
\end{tabular}

Short-run

\begin{tabular}{|c|c|c|c|c|c|c|c|c|c|c|c|c|}
\hline $\mathrm{D}(\mathrm{BB})$ & 0.021 & 0.463 & & & & & 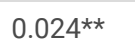 & 2.060 & & & & \\
\hline $\mathrm{D}(\mathrm{BB}(-1))$ & 0.002 & 0.125 & & & & & & & & & & \\
\hline $\mathrm{D}(\mathrm{BB}(-2))$ & 0.060 & 1.144 & & & & & & & & & & \\
\hline $\mathrm{D}(\mathrm{BC}(-1))$ & & & 0.037 & 0.692 & & & & & 0.301 & 1.323 & & \\
\hline $\mathrm{D}(\mathrm{BC}(-2))$ & & & & & & & & & 0.004 & 0.021 & & \\
\hline $\mathrm{D}(\mathrm{BC}(-2))$ & & & & & & & & & 0.449 & 1.610 & & \\
\hline D(INSURANCE) & & & & & $-0.028^{\star}$ & 1.815 & & & & & $-0.016 *$ & 1.96: \\
\hline D(INSURANCE(-1)) & & & & & & & & & & & -0.008 & 0.15 ! \\
\hline $\mathrm{D}(\mathrm{EC})$ & 0.207 & 1.170 & $0.262^{\star \star}$ & 2.313 & 0.214 & 1.538 & 0.206 & 0.704 & $0.565^{\star \star}$ & 2.024 & 0.090 & $0.29 !$ \\
\hline $\mathrm{D}(\mathrm{EC}(-1))$ & 0.080 & 0.551 & & & & & & & -0.060 & 0.282 & -0.070 & $0.55 \uparrow$ \\
\hline $\mathrm{D}(\mathrm{EC}(-2))$ & -0.064 & 0.620 & & & & & & & 0.241 & 1.240 & & \\
\hline D(TRADE) & -0.004 & 0.925 & 0.001 & 0.462 & $0.001^{*}$ & 1.769 & $0.001^{\star \star}$ & 2.372 & 0.000 & 0.038 & $0.002^{\star \star \star}$ & $2.96 !$ \\
\hline $\mathrm{D}(\operatorname{TRADE}(-1))$ & -0.003 & 1.525 & & & & & & & 0.000 & 0.257 & 0.000 & 0.27 \\
\hline $\mathrm{D}(\operatorname{TRADE}(-2))$ & -0.003 & 1.470 & & & & & & & $-0.004 * \star$ & 2.283 & & \\
\hline $\mathrm{D}(\mathrm{POP})$ & -0.002 & 0.002 & 0.170 & 1.589 & -0.003 & 0.059 & 0.084 & 0.323 & -0.265 & 0.519 & 0.158 & $0.97:$ \\
\hline $\mathrm{D}(\mathrm{POP}(-1))$ & 0.759 & 0.401 & & & & & & & 0.812 & 0.532 & -0.098 & 0.75 \\
\hline $\mathrm{D}(\mathrm{POP}(-2))$ & -0.556 & 0.807 & & & & & & & -0.561 & 0.515 & & \\
\hline C & 0.202 & 1.086 & 0.060 & 0.561 & -0.180 & 1.136 & $1.706^{\star \star \star}$ & 2.805 & 0.783 & 0.716 & 0.472 & $2.36 t$ \\
\hline \multicolumn{13}{|l|}{ Diagnostics } \\
\hline Log-likelihood & 368.1 & & 351.5 & & 330.1 & & 272.6 & & 292.1 & & 279.0 & \\
\hline $\operatorname{ECM}(-1)$ & $-0.151^{*}$ & 1.906 & $0.212^{\star \star}$ & 2.327 & $-0.173^{\star}$ & 1.738 & $-0.329 * * *$ & 2.791 & $0.294^{\star \star}$ & 2.136 & $-0.292^{\star *}$ & $2.69 !$ \\
\hline Kao- cointegration & $-2.723^{\star \star \star}$ & 3.000 & $-2.365^{\star \star \star}$ & & $-2.945^{\star \star \star}$ & & $-3.845^{\star \star \star}$ & & $-2.635^{\star \star \star}$ & & $-4.254^{\star * \star}$ & \\
\hline Hausman & 0.221 & & 1.235 & & 1.354 & & 1.355 & & 1.355 & & 0.124 & \\
\hline
\end{tabular}

Note: ${ }^{* \star *} p<0.01 ;{ }^{* \star} p<0.05 ;$ and ${ }^{*} p<0.1$

Financial inclusion also backs the accomplishment of financial resources in all sections of the economy at an inexpensive rate that could help to lubricate the wheel of the economy (Bhasker, 2013). These findings are consistent with the findings of some previous studies such as Dixit and Ghosh (2013), Onaolapo (2015), and Sharma (2016). According to the world bank (2014), financial inclusion helps the easy provision of financial services to the larger population of the society by increasing the number of financial institutions. As a result, the growth of the economy increases which in turn improves the living standard of the people and reduces poverty.

The control variables EC and Trade helps the economy to grow as well - a 1\% rise in EC improves the economic growth of the country by $0.853 \%, 1.739 \%$, and $1.628 \%$ and a $1 \%$ rise in Trade improves the economic growth of the economy by $0.032 \%, 0.039 \%$, and $0.012 \%$. However, a $1 \%$ rise in the POP only improves the economic growth in the first model by $0.458 \%$ whereas it is not statistically noticeable in the second and third models.

Now we will discuss the long-run estimates of $\mathrm{CO} 2$ models. The estimated coefficients of BB and BC are positively significant, whereas the estimated coefficient of Insurance is significantly negative. In the elasticity form, we can elaborate these results by saying that a $1 \%$ rise in the bank branches and credit 
facilities by banks increases the CO2 emissions by $0.015 \%$ and $0.1417 \%$. However, a $1 \%$ rise in Insurance decreases the $\mathrm{CO} 2$ emissions by $0.0181 \%$. Theory suggests that financial inclusion can affect the environment positively or negatively. Our results are suggesting that improved financial inclusion due to the increased number of bank branches and credits facilities help the financial sector to develop and grow which is considered as a driver in nurturing the economy due to the surge in the availability of production and consumption loans that also increase the energy demand and thus give rise to CO2 emissions (Frankel and Romer, 1999). On the other side, as the economy grows due to better financial inclusion of the society more sophisticated and advanced technologies developed in the production process can help to reduce $\mathrm{CO} 2$ emissions. Similarly, the availability of credit facilities also speeds up the investment in renewable energy projects that also exert less burden on the environment. Banks provide individual loans for energy-efficient products such as LEDs, DC inverters, fuel-efficient cars, etc., besides banks also provide easy credit to the house owners for installing solar energy. The positive impact of financial inclusion on $\mathrm{CO} 2$ emissions is supported by le et al. (2020), however, Renzhi and Baek (2020) found an inverted U-shape relationship between CO2 emissions and financial inclusion.

The variable of energy consumption exerted a positive impact on the $\mathrm{CO} 2$ emissions in all the models by the amount of $1.259 \%, 1.992 \%$, and $1.635 \%$. Conversely, a $1 \%$ rise in Trade reduces the $\mathrm{CO} 2$ emissions by $0.004 \%$ only in model six, whereas in models four \& five the impact of Trade is insignificant. Finally, the estimated coefficient of POP $(0.557 \%)$ is significant and negative in model four, while insignificant in models five \& six. In the short run, the estimates in the GDP models are providing us with an inconclusive picture as most of them are insignificant and appeared with mixed signs at most lags. Similarly, the short-run estimates in all $\mathrm{CO} 2$ models are mostly insignificant and provide inconclusive results.

Table 4, provide the results of the Granger causality which confirm one-way causality running from $\mathrm{GDP} \rightarrow \mathrm{BC}, \mathrm{GDP} \rightarrow \mathrm{Insurance}, \mathrm{CO} 2 \rightarrow \mathrm{BC}$, Insurance $\rightarrow \mathrm{CO} 2$. However, bi-directional causality is found between GDP↔BB. For detailed results see Table 4.

Table 4: Panel causality test results 
Null Hypothesis:

W-Stat. Zbar-Stat. Prob. Null Hypothesis:

W-Stat. Zbar-Stat. Prob.

\begin{tabular}{|c|c|c|c|c|c|c|c|}
\hline $\mathrm{BB} \rightarrow \mathrm{GDP}$ & 4.446 & 1.925 & 0.054 & $\mathrm{BB} \rightarrow \mathrm{CO} 2$ & 3.444 & 1.047 & 0.295 \\
\hline $\mathrm{GDP} \rightarrow \mathrm{BB}$ & 4.195 & 1.704 & 0.088 & $\mathrm{CO} 2 \rightarrow \mathrm{BB}$ & 3.535 & 1.126 & 0.260 \\
\hline $\mathrm{BC} \rightarrow \mathrm{GDP}$ & 2.835 & 0.513 & 0.608 & $\mathrm{BC} \rightarrow \mathrm{CO} 2$ & 3.199 & 0.832 & 0.406 \\
\hline $\mathrm{GDP} \rightarrow \mathrm{BC}$ & 7.523 & 4.621 & 0.000 & $\mathrm{CO} 2 \rightarrow \mathrm{BC}$ & 4.851 & 2.280 & 0.023 \\
\hline INSURANCE $\rightarrow$ GDP & 2.093 & -0.138 & 0.890 & INSURANCE $\rightarrow$ CO2 & 5.105 & 2.502 & 0.012 \\
\hline GDP $\rightarrow$ INSURANCE & 5.182 & 2.570 & 0.010 & $\mathrm{CO} 2 \rightarrow$ INSURANCE & 2.947 & 0.611 & 0.542 \\
\hline $\mathrm{EC} \rightarrow \mathrm{GDP}$ & 3.154 & 0.792 & 0.428 & $\mathrm{EC} \rightarrow \mathrm{CO} 2$ & 5.019 & 2.427 & 0.015 \\
\hline $\mathrm{GDP} \rightarrow \mathrm{EC}$ & 3.533 & 1.124 & 0.261 & $\mathrm{CO} 2 \rightarrow \mathrm{EC}$ & 5.356 & 2.722 & 0.007 \\
\hline TRADE $\rightarrow$ GDP & 3.795 & 1.354 & 0.176 & TRADE $\rightarrow$ CO2 & 3.94 & 1.482 & 0.139 \\
\hline $\mathrm{GDP} \rightarrow \mathrm{TRADE}$ & 7.742 & 4.813 & 0.000 & $\mathrm{CO} 2 \rightarrow \mathrm{TRADE}$ & 10.713 & 7.418 & 0.000 \\
\hline $\mathrm{POP} \rightarrow \mathrm{GDP}$ & 5.853 & 3.158 & 0.002 & $\mathrm{POP} \rightarrow \mathrm{CO} 2$ & 2.721 & 0.413 & 0.680 \\
\hline $\mathrm{GDP} \rightarrow \mathrm{POP}$ & 11.27 & 7.906 & 0.000 & $\mathrm{CO} 2 \rightarrow \mathrm{POP}$ & 11.023 & 7.689 & 0.000 \\
\hline $\mathrm{BC} \rightarrow \mathrm{BB}$ & 3.505 & 1.100 & 0.271 & $\mathrm{BC} \rightarrow \mathrm{BB}$ & 3.505 & 1.100 & 0.271 \\
\hline $\mathrm{BB} \rightarrow \mathrm{BC}$ & 2.656 & 0.356 & 0.722 & $\mathrm{BB} \rightarrow \mathrm{BC}$ & 2.656 & 0.356 & 0.722 \\
\hline INSURANCE $\rightarrow$ BB & 2.943 & 0.607 & 0.544 & INSURANCE $\rightarrow$ BB & 2.943 & 0.607 & 0.544 \\
\hline $\mathrm{BB} \rightarrow$ INSURANCE & 3.732 & 1.299 & 0.194 & $\mathrm{BB} \rightarrow$ INSURANCE & 3.732 & 1.299 & 0.194 \\
\hline $\mathrm{EC} \rightarrow \mathrm{BB}$ & 5.538 & 2.882 & 0.004 & $\mathrm{EC} \rightarrow \mathrm{BB}$ & 5.538 & 2.882 & 0.004 \\
\hline $\mathrm{BB} \rightarrow \mathrm{EC}$ & 4.188 & 1.699 & 0.089 & $\mathrm{BB} \rightarrow \quad \mathrm{EC}$ & 4.188 & 1.699 & 0.089 \\
\hline TRADE $\rightarrow$ BB & 3.177 & 0.813 & 0.416 & TRADE $\rightarrow$ BB & 3.177 & 0.813 & 0.416 \\
\hline $\mathrm{BB} \rightarrow \quad \mathrm{TRADE}$ & 3.918 & 1.462 & 0.144 & $\mathrm{BB} \rightarrow \mathrm{TRADE}$ & 3.918 & 1.462 & 0.144 \\
\hline $\mathrm{POP} \rightarrow \mathrm{BB}$ & 3.975 & 1.512 & 0.131 & $\mathrm{POP} \rightarrow \mathrm{BB}$ & 3.975 & 1.512 & 0.131 \\
\hline $\mathrm{BB} \rightarrow \mathrm{POP}$ & 25.33 & 20.232 & 0.000 & $\mathrm{BB} \rightarrow \mathrm{POP}$ & 25.33 & 20.232 & 0.000 \\
\hline INSURANCE $\rightarrow$ BC & 2.548 & 0.261 & 0.794 & INSURANCE $\rightarrow$ BC & 2.548 & 0.261 & 0.794 \\
\hline $\mathrm{BC} \rightarrow$ INSURANCE & 1.458 & -0.694 & 0.488 & $\mathrm{BC} \rightarrow$ INSURANCE & 1.458 & -0.694 & 0.488 \\
\hline $\mathrm{EC} \rightarrow \mathrm{BC}$ & 6.12 & 3.392 & 0.001 & $\mathrm{EC} \rightarrow \mathrm{BC}$ & 6.120 & 3.392 & 0.001 \\
\hline $\mathrm{BC} \rightarrow \mathrm{EC}$ & 4.468 & 1.944 & 0.052 & $\mathrm{BC} \rightarrow \mathrm{EC}$ & 4.468 & 1.944 & 0.052 \\
\hline TRADE $\rightarrow$ BC & 4.072 & 1.597 & 0.110 & TRADE $\rightarrow$ BC & 4.072 & 1.597 & 0.11 \\
\hline $\mathrm{BC} \rightarrow \mathrm{TRADE}$ & 3.967 & 1.505 & 0.132 & $\mathrm{BC} \rightarrow \mathrm{TRADE}$ & 3.967 & 1.505 & 0.132 \\
\hline $\mathrm{POP} \rightarrow \mathrm{BC}$ & 3.031 & 0.685 & 0.494 & $\mathrm{POP} \rightarrow \mathrm{BC}$ & 3.031 & 0.685 & 0.494 \\
\hline $\mathrm{BC} \rightarrow \mathrm{POP}$ & 3.595 & 1.179 & 0.239 & $\mathrm{BC} \rightarrow \mathrm{POP}$ & 3.595 & 1.179 & 0.239 \\
\hline EC $\rightarrow$ INSURANCE & 5.806 & 3.116 & 0.002 & $\mathrm{EC} \rightarrow$ INSURANCE & 5.806 & 3.116 & 0.002 \\
\hline INSURANCE $\rightarrow$ EC & 5.171 & 2.561 & 0.011 & INSURANCE $\rightarrow$ EC & 5.171 & 2.561 & 0.011 \\
\hline TRADE $\rightarrow$ INSURANCE & 3.082 & 0.729 & 0.466 & TRADE $\rightarrow$ INSURANCE & 3.082 & 0.729 & 0.466 \\
\hline INSURANCE $\rightarrow$ TRADE & 5.157 & 2.548 & 0.011 & INSURANCE $\rightarrow$ TRADE & 5.157 & 2.548 & 0.011 \\
\hline $\mathrm{POP} \rightarrow$ INSURANCE & 2.659 & 0.359 & 0.720 & $\mathrm{POP} \rightarrow$ INSURANCE & 2.659 & 0.359 & 0.720 \\
\hline INSURANCE $\rightarrow$ POP & 9.153 & 6.05 & 0.000 & INSURANCE $\rightarrow$ POP & 9.153 & 6.050 & 0.000 \\
\hline TRADE $\rightarrow$ EC & 7.232 & 4.367 & 0.000 & TRADE $\rightarrow$ EC & 7.232 & 4.367 & 0.000 \\
\hline $\mathrm{EC} \rightarrow \mathrm{TRADE}$ & 7.802 & 4.866 & 0.000 & $\mathrm{EC} \rightarrow \mathrm{TRADE}$ & 7.802 & 4.866 & 0.000 \\
\hline $\mathrm{POP} \rightarrow \mathrm{EC}$ & 4.548 & 2.014 & 0.044 & $\mathrm{POP} \rightarrow \mathrm{EC}$ & 4.548 & 2.014 & 0.044 \\
\hline $\mathrm{EC} \rightarrow \mathrm{POP}$ & 6.054 & 3.334 & 0.001 & $\mathrm{EC} \rightarrow \mathrm{POP}$ & 6.054 & 3.334 & 0.001 \\
\hline $\mathrm{POP} \rightarrow \mathrm{TRADE}$ & 4.631 & 2.087 & 0.037 & $\mathrm{POP} \rightarrow \mathrm{TRADE}$ & 4.631 & 2.087 & 0.037 \\
\hline TRADE $\rightarrow$ POP & 2.623 & 0.327 & 0.744 & TRADE $\rightarrow$ POP & 2.623 & 0.327 & 0.744 \\
\hline
\end{tabular}


Note: ${ }^{* *} p<0.01 ; * * p<0.05 ;$ and ${ }^{*} p<0.1$

\section{Conclusion And Policy Implications}

The objective of the study is to investigate the role of financial inclusion on environmental quality and economic performance in the top five emerging economies of Asia including China, India, Japan, Indonesia, and Turkey for the period 1995 to 2019. Bank branches, bank credit, and insurance premiums are used to measure financial inclusion. The panel-ARDL method is employed for empirical investigation. It is found that long-run panel cointegration exists between the focused variables of the study. In the long-run, bank branches impact on economic and environmental performance is positive inferring that as the bank branches increase it leads to increase economic performance and pollution emissions. Bank credit also results in increasing economic growth and pollution emissions in the long-run. The impact of insurance premium on economic performance is statistically insignificant revealing that there is no association between the insurance premium and economic growth in the long run. However, insurance premiums exert a significant negative impact on carbon emissions confirming that the increase in insurance premiums results in reducing carbon emissions in the long-run. It is also evident that energy consumption is positively associated with economic growth and pollution emissions in the long-run. Trade impact is positive on economic growth in all three models but this effect is negative on pollution emissions only in the insurance premium regression model in the long-run. Population growth has a significant impact on economic-environmental performance only in bank branches regression in the long-run. In the short-run, bank branches have a positive impact on carbon emission revealing that an increase in bank branches results in rising carbon emissions. Bank credit has no association with the economic-environmental performance nexus in the short-run. Insurance premium impact is negative on economic-environment performance in the short-run concluding that due to an increase in insurance premium economic growth and carbon emissions will decrease.

Authorities and policymakers of these economies should follow and embrace mitigation methods, including the adoption and installation of digital financial inclusion in the future. Asian emerging markets should maintain sustainable development via financial inclusion. Through financial inclusion, the funds from the financial institutions can be directed towards the projects of green and clean energy. Moreover, the funds should be transferred to those firms, businesses, and individuals who are involved in green innovations. The government should also articulate strict rules for the financial institutions to lend finance for renewable energy and environmental-friendly projects, and this can be more fruitful through digital financial inclusion. The governments should also remove barriers from digital financial inclusion such as affordability, documentation, and trust.

The study has a limitation of the availability of data. The data on digital financial inclusion is not available earlier than 2004 . Therefore, we have not included digital financial inclusion in the analysis. This study used only three variables of financial inclusion based on usage and access to the formal financial services factors, while many other factors were not considered in the analysis due to the unavailability of relevant data for the Asian emerging economies. Future studies should also use other proxies of digital financial inclusion. Future studies can be conducted on the same topic by covering more updated models and data. Future researchers may also analyze at the micro-level in the high-polluted economy.

\section{Declarations}

Ethical Approval: Not applicable

Consent to Publish: Not applicable

Authors Contributions: This idea was given by Liu Dong and Yuantao Xie. Muhammad Hafeez, Liu Dong, Yuantao Xie, and Ahmed Usman collected the data, computed data analysis and wrote the complete paper. While Liu Dong and Yuantao Xie read and approved the final version.

Consent to Participate: I am free to contact any of the people involved in the research to seek further clarification and information

Funding: Not applicable.

Competing interests: The authors declare that they have no conflict of interest.

Availability of data and materials: The datasets used and/or analyzed during the current study are available from the corresponding author on reasonable request.

\section{References}

1. Ahmad, M., Majeed, A., Khan, M. A., Sohaib, M., \& Shehzad, K. (2021). Digital financial inclusion and economic growth: Provincial data analysis of China. China Economic Journal, 1-20.

2. Baulch, B., Do, T. D., \& Le, T. H. (2018). Constraints to the uptake of solar home systems in Ho Chi Minh City and some proposals for improvement. Renewable energy, 118, 245-256.

3. Dahiya, S., \& Kumar, M. (2020). Linkage between financial inclusion and economic growth: An empirical study of the emerging Indian economy. Vision, 24(2), 184-193.

4. Dixit, R., \& Ghosh, M. (2013). Financial inclusion for inclusive growth of India-A study of Indian states. International Journal of Business Management \& Research, 3(1), 147-156.

5. Emara, N., \& El Said, A. (2021). Financial inclusion and economic growth: The role of governance in selected MENA countries. International Review of Economics \& Finance, 75, 34-54.

6. Hatemi-j, A. (2012). Asymmetric causality tests with an application. Empirical economics, 43(1), 447-456. 
7. Kim, M., Zoo, H., Lee, H., \& Kang, J. (2018). Mobile financial services, financial inclusion, and development: A systematic review of academic literature. The Electronic Journal of Information Systems in Developing Countries, 84(5), e12044.

8. Le, T. H., Le, H. C., \& Taghizadeh-Hesary, F. (2020). Does financial inclusion impact C02 emissions? Evidence from Asia. Finance Research Letters, 34, 101451.

9. Makina, D., \& Walle, Y. M. (2019). Financial inclusion and economic growth: evidence from a panel of selected african countries. In Extending Financial Inclusion in Africa (pp. 193-210). Academic Press.

10. Onaolapo, A. R. (2015). Effects of financial inclusion on the economic growth of Nigeria (1982-2012). International Journal of Business and Management Review, 3(8), 11-28.

11. Pesaran, M. H., Shin, Y., \& Smith, R. P. (1999). Pooled mean group estimation of dynamic heterogeneous panels. Journal of the American statistical Association, 94(446), 621-634.

12. Qin, L., Raheem, S., Murshed, M., Miao, X., Khan, Z., \& Kirikkaleli, D. (2021). Does financial inclusion limit carbon dioxide emissions? Analyzing the role of globalization and renewable electricity output. Sustainable Development.

13. Raheem, I. D., Tiwari, A. K., \& Balsalobre-Lorente, D. (2020). The role of ICT and financial development in CO 2 emissions and economic growth. Environmental Science and Pollution Research, 27(2), 1912-1922.

14. Rahim, N., Wan, K., \& Franceschelli, M. (2009). Financial inclusion amongst new migrants in Northern Ireland: A literature review. London: Information Centre about Asylum and Refugees.

15. Renzhi, N., \& Baek, Y. J. (2020). Can financial inclusion be an effective mitigation measure? evidence from panel data analysis of the environmental Kuznets curve. Finance Research Letters, 37, 101725.

16. Reserve Bank of India. (2013). Basic Statistical Returns of Scheduled Commercial Banks in India. Director, Banking Statistics Division, Department of Statistics and Information Management, Reserve Bank of India.

17. Sarma, M., \& Pais, J. (2011). Financial inclusion and development. Journal of international development, 23(5), 613-628.

18. Sharma, D. (2016). Nexus between financial inclusion and economic growth: Evidence from the emerging Indian economy. Journal of Financial Economic Policy, 8(1), 13-36.

19. Singh, D., \& Stakic, N. (2021). Financial inclusion and economic growth nexus: Evidence from SAARC countries. South Asia Research, 41(2), $238-258$.

20. Swamy, V. (2014). Financial inclusion, gender dimension, and economic impact on poor households. World Development, 56, 1-15.

21. Van, L. T. H., Vo, A. T., Nguyen, N. T., \& Vo, D. H. (2021). Financial inclusion and economic growth: An international evidence. Emerging Markets Finance and Trade, 57(1), 239-263.

22. Zaidi, S. A. H., Hussain, M., \& Zaman, Q. U. (2021). Dynamic linkages between financial inclusion and carbon emissions: Evidence from selected OECD countries. Resources, Environment and Sustainability, 4, 100022. 